\title{
Perbedaan Display Toko Offline dan Toko Online Untuk Produk Pakaian Wanita
}

\author{
Heni Iswati ${ }^{1}$, Nina Maharani ${ }^{2}$ \\ ${ }^{1}$ Program Magister Managemen Universitas Budi Luhur, ${ }^{2}$ Fakultas Ekonomi dan Bisnis-Manajemen, Universitas \\ Islam Bandung (Unisba) \\ 'heni.iswati@gmail.com, 2nina.maharani68@gmail.com
}

\begin{abstract}
ABSTRAK
Seiring dengan perkembangan teknologi, cara membeli produk pakaian pun mengalami pergeseran. Pembelian melalui toko offline dimana konsumen langsung datang ke toko untuk membeli, dan melalui toko online dimana konsumen dapat berbelanja melalui gadget kapan pun dan dimana pun. Tujuan penelitian ini adalah untuk mengetahui persepsi dan perbedaan terhadap display toko offline dan toko online. Metode yang digunakan adalah deskriptif dan kuantitatif terhadap 400 responden di Kota Bandung yang pernah mengakses atau melakukan pembelian produk pakaian wanita melalui toko offline dan online. Hasil penelitian menunjukkan terdapat perbedaan antara display toko offline dan online. Dalam hal kepraktisan dalam membeli dan waktu, toko online mendapatkan respon yang baik, sedangkan pada informasi dan kualitas produk, toko online mendapatkan respon yang kurang. Mengenai harga, tidak mengalami perbedaan yang signifikan diantara toko offline dan online. Walaupun terdapat perbedaan diantara toko offline dan online, tidak mematikan pasaran dan sistem penjualan yang dilakukan diantara keduanya. Karena perbedaan tersebut menjadikan kedua toko menjadi unik. Namun secara keseluruhan toko online lebih diminati karena kemudahannya saat diakses oleh konsumen.
\end{abstract}

Kata Kunci : toko offline, toko online, display

\section{ABSTRACT}

The way to buy clothing products shifted, along with technology growth. Purchases through an offline store where consumers come directly to the store to buy, and through online stores where consumers can shop through gadgets anytime and anywhere. The purpose of this study was to determine the perceptions and differences of offline store and online stores displays. The method used was descriptive and quantitative about 400 respondents in the city of Bandung. Whereas previously the respondents had also accessed or purchased women's clothing products through offline and online stores. Based on the results obtained there are differences between offline and online store displays. In terms of practicality in buying and time, online stores get a good response, while in the information and quality of products, online stores get less response. Regarding prices, there is no significant difference between offline and online stores. Although there are differences between offline and online stores, they do not turn off the market and the sales system that is carried out between the two shops. Because these differences make the two stores unique. But overall the online store is more in demand because of its ease when accessed by consumers.

Keywords: offline shop, online shop, display

\section{PENDAHULUAN}

\section{Latar Belakang}

Bandung merupakan kota besar di Indonesia yang menduduki peringkat ke-empat berdasarkan jumlah penduduknya, dengan jumlah penduduk sebanyak 2.341.097 jiwa.(www.ilmupengetahuanumum.com). Bandung telah berkembang dan mampu bersaing dengan kota besar lainnya di Indonesia, Selain dikenal dengan "Paris Van Java Indonesia" Bandung dikenal juga sebagai salah satu kota industri kreatif. Industri kreatif mempunyai beberapa sub sektor diantaranya adalah: Fashion, kerajinan, periklanan, penerbitan \& percetakan serta musik, sub sektor fashion memberikan kontibusi persentase Produk Domestik Bruto terbesar di kota Bandung yaitu sebesar 43.71\% (Kompas, 3 Juli 2015). Industri fashion berkembang pesat di kota 
Bandung dikarenakan banyaknya produsen produk fashion, tidak hanya dari toko skala kecil namun juga dalam skala besar serta tersebar di banyak pusat perbelanjaan di Kota Bandung terutama yang memfokuskan pada fashion pakaian wanita. Seperti pusat perbelanjaan di Pasar Baru, Balubur, Bandung Trade Center, factory outlet di Jalan Riau, produsen pakaian muslim untuk wanita seperti Rabbani dan Zoya, Elzatta, Dauky dan banyak lagi. Hal ini ditunjang dengan pertumbuhan distro, dan clothing yang meningkat pesat dari tahun ke tahun, sehingga memperkuat image Bandung sebagai Kota Fashion.

Banyaknya toko offline yang menawarkan produk pakaian wanita menyebabkan persaingan yang ketat diantara berbagai toko tersebut, salah satu faktor yang dapat menjadikan toko offline-lebih menonjol di bandingkan toko offline pesaing dengan menerapkan display yang menarik. Grewal et, al (2017) berpendapat di masa depan salah satu faktor yang dapat membuat produk terlihat lebih menonjol dari pesaing di rak ataupun secara online adalah dengan menggunakan tampilan visual. Gudonavičienè \& Alijošienè (2015) menyatakan lingkungan penjualan yang menarik adalah hasil dari berbagai kombinasi elemen visual merchandising dapat mempengaruhi emosi dan perilaku pembelian konsumen, dan mempengaruhi niat beli konsumen (Clement, 2007) Gajanayake \& Gajayanake (2011) serta Merugu \& Vaddadi (2017) menyatakan elemen-elemen visual merchandising terdiri dari warna, display produk, kebersihan, pencahayaan dan musik serta layout toko.

Toko offline merupakan toko yang menawarkan banyak produk memasang produk baru dan andalannya dengan memajangnya di jendela depan toko dengan harga khusus, memajang berbagai macam produk pakaian dengan menggunakan berbagai manekin dengan bentuk penyusunan yang berbeda, penulisan merek toko dengan mencolok, bentuk dan warna tulisan yang berbeda akan mampu menjadi penciri pembeda antara satu toko dan toko lainnya Pemandangan seperti ini sering ditemui pada toko-toko pakaian di Kota Bandung

Perkembangan teknologi informasi saat ini menggeser kebiasaan dalam membeli ataupun kebutuhan sandang yang biasanya dilakukan dengan mendatangi toko secara langsung bergeser menjadi membeli secara online. Dengan adanya internet, aktivitas belanja online kini sudah menjadi alternatif berbelanja yang lazim di kalangan masyarakat Bandung. Dalam transaksi online, konsumen sepenuhnya bergantung pada kepercayaan atas informasi yang disampaikan dalam bentuk Website. Di Indonesia transaksi online terus meningkat. Ini dapat dilihat dari jumlah pembeli online dari serta jumlah toko online di berbagai media online dari tahun ke tahun yang juga terus meningkat (Siagian \& Cahyono 2014).

Di Indonesia 50 Juta pengguna jasa e-commerce dengan pengguna terbanyak terdapat pada online shopping dan aplikasi ojek online (Fatimah, 2019). Data dari Asosiasi Penyelenggara Jasa Internet Indonesia (APJII), sampai Januari 2016, pengguna internet di Indonesia mencapai 88,1 juta, di mana 48 persennya merupakan pengguna internet harian (www.medcom.id). Berdasarkan data dari id.techinasia.com, tiga barang yang paling sering dibeli secara online adalah: pakaian, sepatu dan tas. Usia pengguna internet di Indonesia paling tinggi adalah usia muda, 19 hingga 34 tahun sebanyak 49,52 persen. Di posisi kedua, sebanyak 29,55 persen pengguna internet Indonesia berusia 35 hingga 54 tahun. (www.tekno.kompas.com).

Di Indonesia, belanja online dapat dilakukan melalui e-commerce, marketplace dan toko online. Contoh e-commerce adalah Zalora dan Blibli.com; marketplace seperti Tokopedia, Lazada, Elevenia, Bukalapak; dan juga ada yang menawarkan toko online melalui blog, forum jual beli seperti Kaskus, media sosial seperti Facebook, Twitter, dan juga Instagram. Banyak juga toko online yang menjadi reseller dari sebuah brand tertentu yang pada akhirnya tertarik untuk melakukan penjualan online pada website-nya sendiri. Semakin meningkatnya jumlah toko online maka salah satu cara menarik perhatian konsumen membeli produk online adalah dengan menampilkan display web yang lebih baik dibanding pesaing. Display toko online yang mudah dalam penggunaan, berguna, menyenangkan ketika digunakan, personalisasi dan 
menciptakan interaksi sosial dapat menciptakan pengalaman belanja yang baik sehingga menciptakan kepuasan dan loyalitas (Bilgihan et al, 2016). Katradjiev dan Ivo (2014) menambahkan web graphis yang menarik serta tersedianya informasi produk dan layanan adalah alat penting untuk menarik perhatian, memuaskan dan mempertahankan konsumen.

Sistem belanja online ini menawarkan sejumlah keuntungan yaitu kenyamanan dalam hal waktu, jangkauan serta keanekaragaman barang (Katawetawaraks, 2011). Konsumen dengan mudah menemukan barang-barang yang dibutuhkannya tanpa perlu mencarinya hingga ke tempat yang jauh. Cukup dengan memasukkan kata kunci yang sesuai produk yang sedang dicari pada mesin pencarian atau pada search bar setiap situs website toko online.

Pengguna jasa online shopping di Indonesia sekitar 50 juta orang dan dari tahun ke tahun terus meningkat namun penelitian yang dilakukan ICSC menyatakan bahwa konsumen masih lebih sering melakukan pembelian di toko konvensional dibandingkan online shop, dan $75 \%$ menyatakan hal tersebut dikarenakan mereka ingin mencoba atau menyentuh langsung produk sebelum melakukan pembelian (www.icsc.org, 2015). Hal ini cukup membuktikan bahwa kedudukan dari toko konvensional masih belum tergeser oleh munculnya teknologi digital marketing, meskipun hal ini tetap menjadi ancaman bagi toko konvensional karena perkembangan transaksi dunia maya setap tahunnya selalu bertambah sekitar 30\% per tahun. Perkembangan terbesar transaksi melalui dunia maya paling besar pada perdagangan pakaian disusul oleh bisnis perjalanan dan komputer (Mulyadi, 2015).

Akan terjadi persaingan yang ketat antara toko offline dengan toko online salah satu cara yang akan membedakan satu toko dengan toko lainnya adalah display toko. Sehingga kemampuan produsen dalam menampilkan/display barang di toko menjadi sangat penting untuk menarik minat beli masyarakat.

\section{Identifikasi Masalah}

Bandung dikenal sebagai kota Fashion dikarenakan kontribusi Fashion terhadap Produk Domestik Bruto sebesar $43,71 \%$ serta Banyakanya, sub sektor fashion memberikan kontribusi persentase Produk Domestik Bruto terbesar di kota Bandung yaitu sebesar 43.71\%. Industri fashion berkembang pesat di kota Bandung dikarenakan banyaknya produsen produk fashion, tidak hanya dari toko skala kecil namun juga dalam skala besar serta tersebar di banyak pusat perbelanjaan di Kota Bandung terutama yang memfokuskan pada fashion pakaian wanita seperti di Pasar baru, Balubur, Bandung trade mall dan lain-lain. Hal ini menyebabkan persaingan ketat diantara berbagai toko yang menyediakan pakaian wanita.

Display toko yang dapat menarik minat belanja, memuaskan dan mempertahankan konsumen adalah : Mudah dalam penggunaan, berguna, menyenangkan ketika digunakan, personalisasi dan menciptakan interaksi sosial, web graphis yang menarik serta tersedianya informasi produk dan layanan. Walaupun transaksi penjualan melalui internet berkembang $30 \%$ pertahun dengan transaksi terbesar dalam perdagangan pakaian, namun $75 \%$ konsumen masih sering belanja di toko konvensional dibandingkan toko online dikarenakan mereka ingin menyentuh langsung produk sebelum melakukan pembelian.

\section{Rumusan masalah}

Berdasarkan Identifikasi masalah diatas, maka rumusan masalah dalam penelitian ini adalah terdapat perbedaan yang dihadapi oleh toko offline atau toko konvensional dan toko online dalam menampilkan/ mendisplay produk yang ditawarkan. 
Jurnal Manajemen dan Bisnis: Performa Vol.16, No. 2 September 2019

\section{LANDASAN TEORI}

\section{Display Toko Offline}

Alma (2009:189) mendefinisikan display yaitu usaha mendorong perhatian dan minat konsumen pada toko atau barang dan mendorong keinginan membeli melalui daya Tarik penglihatan langsung (direct visual appeal). Menurut Alfiyah (2017) display adalah usaha yang dilakukan untuk menata barang yang mengarahkan pembeli agar tertarik untuk melihat dan membeli. Display barang sangat penting dilakukan, karena display yang baik akan menimbulkan minat pelanggan untuk membelinya. Menempatkan barang merupakan hal yang penting terutama penempatan barang dalam windows display, interior display, dan exterior display. Selanjutnya, menurut Alma (2009:189) Windows Display Yaitu memjangkan barangbarang, gambar-gambar kartu harga, simbol-simbol dan sebagainya di bagian toko yang disebut etalase. Dengan demikian calon konsumen yang lewat di muka toko-toko diharapkan akan tertarik oleh barangbarang tersebut dan ingin masuk ke dalam toko. Wajah toko akan berubah jika windows display diganti. Fungsi windows display ini mempunyai beberapa tujuan sebagai berikut: (a.) Untuk menarik perhatian orangorang yang lewat. (b) Untuk menimbulkan impulse buying, (c) menimbulkan daya tarik keseluruhan toko.

Interior Display yaitu memajangkan barang-barang, gambar-gambar, kartu-kartu harga, poster-poster di dalam toko misalnya di lantai, di meja, di rak-rak dan sebagainya. Interior display ini ada beberapa macam: (1) Merchandise Display adalah Barang-barang dagangan dipajangkan di dalam toko dan ada tiga bentuk memajangnya yaitu : Open Display, Closed display serta architecture display. (2) Store Sign and Decoration berupa tanda-tanda, simbol-simbol, lambang-lambang, poster-poster, gambar-gambar, bendera-bendera, semboyan-semboyan dan sebagainya disimpan di atas meja atau digantung di dalam toko. Store design digunakan untuk membimbing calon pembeli ke arah barang dagangan dan memberi keterangan kepada mereka tentang kegunaan barang-baranng tersebut. Decoration pada umumnya digunakan dalam rangka peristiwa khusus seperti penjualan pada saat Hari Raya, Natal, Tahun Baru dan sebagainya. (3) Dealer Display dilaksanakan oleh Wholesaler terdiri dari simbol-simbol petunjuk tentang penggunaan produk, yang kesemuanya berasal dari produsen.

Exterior Display dilaksanakan dengan memajangkan barang-barang diluar toko misalnya, pada waktu mengadakan obral, pasar malam. Display ini mempunyai beberapa fungsi antara lain: (a) Memperkenalkan suatu produk secara tepat dan ekonomis. (b) Membantu para produsen menyalurkan barang-barangnya dengan cepat dan ekonomis. (c) Membantu mengkoordinasikan advertising dan merchandising. Bagi seorang produsen ataupun perantara, tampilan toko offline sangat penting untuk dapat menarik konsumen dengan cara display etalase yang besar, produsen dapat memajang produk unggulan pada tokonya. Selain tampilan pada etalase, tulisan atau icon nama toko juga dapat menjadi poin yang penting dalam penampilan tokonya.

Novianti (2014) menyatakan salah satu hal penting dalam toko yaitu susunan rak dan pengaturan produsen dalam menata produk yang dijual, deretan poster, hiasan dinding, display produk berdasarkan merek, dapat memberikan kesan yang berbeda bagi konsumen serta merefleksikan ciri khas dari toko tersebut. Santy (2016) menambahkan suatu produk baru yang dipajang di luar toko, dapat menarik perhatian konsumen untuk masuk ke dalam toko karena tampilan windows display yang menarik.

\section{Belanja Online}

Katawetawaraks dan Wang (2011) menjelaskan bahwa belanja online adalah kegiatan pembelian produk (baik barang ataupun jasa) melalui media internet. Jusoh \& Ling (2012) menambahkan online shopping sebagai suatu proses dimana seorang pelanggan melakukan pembayaran melalui internet atas barang dan jasa yang dibelinya. Menurut Levy et, al (2014) Online shopping/internet retailing/e-retailing 
adalah pengecer yang berinteraksi dengan para konsumen melalui internet dengan gunakan personal komputer, laptop, tablet ataupun smartphone. Sementara itu, Karakteristik website didefinisikan sebagai atribut yang dipertimbangkan konsumen dalam melakukan penilaian pada website suatu toko online. Karakteristik website diukur menggunakan lima dimensi yaitu (Rahadi, 2013):

Dalam berbelanja melalui media online, konsumen mengharapkan bahwa proses pembelanjaan atau pembelian akan memperoleh kemudahan dalam hal cara, waktu, pemesanan, mengakses dan mengoperasikan websites serta pembelian di media ini. Kemudahan tersebut akan menyebabkan konsumen merasa nyaman dengan penggunaan suatu situs atau web dari toko online tertentu. Selain itu, Situs dengan desain yang menarik akan lebih disukai konsumen. Hal ini menunjukkan bahwa perusahaan harus mampu merancang website perusahaan dengan lebih menarik agar menarik minat konsumen untuk melihat situs sehingga akhirnya akan melakukan pembelian.

Informasi yang disajikan dalam suatu website harus mampu memberikan informasi secara rinci tentang produk yang dijual, cara pemakaian, dan lain sebagainya. Dimensi informatif dapat diukur dengan hal-hal sebagai berikut: informasinya banyak, akurat, beragam serta bermanfaat. Pada saat melakukan pembelian melalui media online, ada beberapa data konsumen yang diketahui oleh penjual. Oleh sebab itu, penjual diharuskan dapat menjaga kerahasiaan identitas pembeli. Selain itu, pihak penjual juga harus memberikan jaminan bahwa transaksi pembelian berlangsung secara aman.

Dalam proses pembelian, konsumen terkadang membutuhkan informasi secara langsung dengan penjual. Berdasarkan hal tersebut maka alamat atau nomor telepon penjual sebaiknya mudah untuk dihubungi. Menurut Kumar (2014) Display toko online adalah Gambar pakaian yang berupa layout desain grafis, yang ada di komputer, tablet, atau telepon seluler konsumen, konsumen tidak dapat menjangkau dan menyentuh pakaian atau bahkan untuk mencoba secara online. Pakaian tersebut tidak dipengaruhi oleh tata letak toko, jendela pajangan di toko yang produsen tampilkan, ataupun skema warna, yang konsumen miliki hanyalah layar dan gambar dari display pada layar gawai.

Terdapat beberapa hal yang harus diperhatikan dalam display produk pada toko online, seperti: (1) Bermain dengan layout design grafis-Dengan menampilkan tampilan awal yang menarik dengan permainan grafis, warna dan tulisan akan menghasilkan tampilan yang mampu menarik perhatian penggunanya. Sehingga dengan tampilan layout yang tepat, produk akan semakin menarik. (2) Pertimbangkan model pemotretan-Bidikan model adalah tambahan yang bagus untuk bidikan produk flat. Sehingga model yang menarik dengan gaya yang berbeda dapat menarik perhatian konsumen. (3) Dapatkan foto-foto yang menarik dan beresolusi tinggi-Foto produk adalah aset no 1 bagi produsen. Foto dibuat sejelas mungkin, tidak berantakan, dan beresolusi tinggi. Zoomability adalah penting, apakah itu otomatis pada saat mouse di-klik (di situs web pada laptop atau komputer) atau dengan metode mengeser jari untuk memperbesar pada layar ponsel. (4) Menulis deskripsi produk dengan jelas dan tepat sasaran-Bagian terakhir adalah produsen harus mengisi semua informasi yang tidak bisa diperoleh pelanggan dari foto yang telah ditampilkan. (5) Tambahkan beberapa video-Video adalah level selanjutnya walaupun hal ini merupakan pilihan yang mahal, dengan hasil yang berpotensi bagus akan semakin dalam tampilan display.

Terdapat hal yang harus diperhatikan pada display pada toko online, yaitu: tampilan homepage atau tampilan awal saat kita membuka toko online, bisa pada website ataupun pada aplikasi toko online. Menurut Agustin \& Koeshartono (2016) konsumen yang mengakses akan melihat tampilan yang muncul pada layar telepon genggam, tulisan atau foto yang muncul haruslah menarik dari segi grafis. Sehingga penggunaan model untuk produk yang difoto adalah penting. Foto yang bagus dengan model yang sesuai dapat menambah nilai positif. Kemudian pembagian kategori produk juga menjadi hal yang harus diperhatikan, dengan disertakannya pemberian deskripsi atas produk yang ditampilkan akan memudahkan konsumen untuk 
memahami produk yang ditawarkan. Selain itu pemberian tambahan video pada laman yang ditampilkan akan lebih menarik konsumen.

Berdasarkan penjabaran serta teori-teori dan penelitian terdahulu, maka dapat digambarkan paradigma penelitian sebagai berikut:

\begin{tabular}{|l|}
\hline Display Toko Offline (X1) \\
Alma (2009:189) \\
1. Windows Display \\
2. Interior Display \\
3. Exterior Display \\
\hline
\end{tabular}

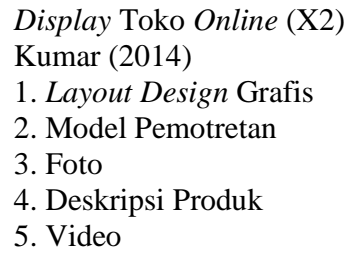

\section{Gambar 2.1. Paradigma Penelitian}

Berdasarkan uraian di atas dapat dilihat dua bentuk sistem display toko yang berbeda, di mana toko offline lebih mengutamakan bentuk fisik dari tampilan tokonya karena dengan nyata dapat dilihat langsung dan dirasakan oleh setiap konsumen yang datang. Tampilan luar toko sampai ke dalam toko harus dapat memberikan pengaruh yang positif bagi konsumen, baik berupa perasaan nyaman ketika berbelanja dan merasa mudah dalam mencari dan mengidentifikasi suatu produk. Ambarwati (2015), menyatakan bahwa toko konvensional masih lebih digemari oleh konsumen karena produk yang akan dibeli dapat langsung dicoba dan terdapat ikatan batin yang lebih dalam dengan wiraniaga toko.

Berbeda dengan toko online, kesan nyata tidak dapat dirasakan karena interaksi yang dilakukan adalah melalui sebuah layar pada telepon genggam atau pun pada perangkat gadget lainnya. Sehingga kesan yang dapat ditimbulkan adalah dari tampilan website atau aplikasi yang digunakan. Semakin bagus dan mudah dipahami dalam mengaksesnya, konsumen akan semakin menyukai laman tersebut. Semakin bagus resolusi foto yang di tampilkan akan memberi kesan lebih pada konsumen sehingga ketertarikan untuk melihat lebih pun ada.

Hipotesis yang diajukan adalah:

H : Terdapat perbedaan Display Toko Offline dan Toko Online Untuk Produk Pakaian Wanita.

\section{METODE PENELITIAN}

Dalam penelitian ini yang menjadi objek penelitian adalah Display Toko Offline sebagai variabel bebas "X1" (independent variable) dan Display Toko Online variabel bebas "X2" (independent variable). Populasi dalam penelitian ini adalah Perempuan di Kota Bandung yang telah berbelanja pakaian baik di toko online maupun toko offline. Variabel penelitian terdiri dari: Display Toko Offline (X1) berdasarkan pendapat Alma (2009): Windows Display, Interior Display, dan Exterior Display. Display Toko Online (X2) berdasarkan pendapat Kumar (2014) : Layout Design Grafis, Model Pemotretan, Foto, Deskripsi Produk, dan Video. Teknik pengambilan sampel melalui accidental sampling. Sampel berjumlah 400 orang, lalu dilakukan uji validitas dan reliabilitas kuesioner. Dengan google form, kuesioner disebarkan. Secara deskriptif penelitian ini bertujuan untuk memperoleh ciri-ciri variabel yang diteliti yaitu Display Toko Offline dan Display Toko Online. Secara vertifikatif, penelitian ini bertujuan untuk mengadakan penelitian sekaligus pengujian kebenaran dari hipotesis yang didasarkan pada data penelitian di lapangan dimana penelitian ini akan diuji. 


\section{HASIL PENELITIAN DAN PEMBAHASAN}

\section{Hasil Penelitian}

Responden pada rentang usia 25-30 tahun memiliki jumlah persentase terbanyak sebesar 32,25\%, kemudian persentase banyak kedua sebesar $29 \%$ pada rentang usia 20-24 tahun. Serta 21,75\% pada rentang usia 31-34 tahun, hal ini menunjukkan bahwa usia dewasa produktif yang gemar melakukan pembelian adalah rentang usia 20-34 tahun. Para mahasiswa mendapatkan persentase terbesar yaitu 25,25\% dalam hal pekerjaan, kemudian persentase kedua adalah sebesar 21,25\% yang dipegang oleh para ibu rumah tangga. Sehingga dapat disimpulkan bahwa mahasiswa dan ibu rumah tangga yang banyak melakukan proses pembelian melalui dua display toko yaitu toko offline dan online.

Pendapatan dengan persentase terbanyak sebesar $42,25 \%$ dikisaran 1 juta $-<2$ juta dan persentase terbanyak kedua adalah sebesar 22,75\% pada kisaran penghasilan 2 juta - < 3 juta rupiah. Menunjukkan bahwa para pembeli pada toko offline dan online adalah para perempuan dengan penghasilan menengah. Hasil jawaban kuesioner mengenai variabel Display Pada Toko Offline seperti disajikan pada tabel-tabel berikut.

Tabel 4.1

Rekapitulasi Variabel Display Toko Offline

\begin{tabular}{|c|c|c|c|c|c|c|c|c|}
\hline \multirow{2}{*}{ No } & \multirow{2}{*}{ Pernyataan } & \multicolumn{5}{|c|}{ Jawaban } & \multirow{2}{*}{ Rata-rata } & \multirow{2}{*}{ Ket } \\
\hline & & STS & TS & KS & $\mathbf{S}$ & SS & & \\
\hline & $\begin{array}{c}\text { Display Pada Toko Offline } \\
\text { (X1) }\end{array}$ & & & & & & & \\
\hline 1. & $\begin{array}{l}\text { Produk yang dipajang pada } \\
\text { etalase. }\end{array}$ & - & - & 161 & 199 & 40 & 3,69 & Baik \\
\hline 2 & $\begin{array}{l}\text { Terdapat penawaran } \\
\text { promosi/diskon pada etalase. }\end{array}$ & - & - & 41 & 239 & 120 & 4,19 & Baik \\
\hline 3 & $\begin{array}{l}\text { Tulisan icon/nama toko } \\
\text { mencolok }\end{array}$ & - & - & 157 & 163 & 80 & 3,8 & Baik \\
\hline 4 & $\begin{array}{l}\text { Penyusunan dan } \\
\text { pengelompokan pakaian sesuai } \\
\text { dengan kategorinya. }\end{array}$ & - & 2 & 198 & 160 & 140 & 3,59 & Baik \\
\hline 5 & $\begin{array}{l}\text { Terdapat poster/gambar yang } \\
\text { menjelaskkan produk. }\end{array}$ & - & - & 230 & 98 & 72 & 3,61 & Baik \\
\hline 6 & $\begin{array}{l}\text { Display sesuai dengan simbol } \\
\text { dari merek produsen }\end{array}$ & - & 4 & 196 & 159 & 41 & 3,59 & Baik \\
\hline 7 & $\begin{array}{l}\text { Produk yang dipajang di luar } \\
\text { toko menarik perhatian. }\end{array}$ & - & - & 198 & 160 & 42 & 3,61 & Baik \\
\hline & Total & - & 6 & 1181 & 1178 & 535 & 3,73 & Baik \\
\hline
\end{tabular}

Sumber: Kuesioner diolah, 2019

Berdasarkan tabel 4.1, penilaian rata- rata responden terhadap display toko sebesar 3.73 berada dalam kategori baik menunjukkan bahwa display yang ditawarkan oleh toko offline dapat diterima dengan baik oleh konsumen. Skor terendah yaitu 3,59 penyusunan \& pengelompokkan pakaian kurang sesuai dengan kategorinya dan display kurang sesuai dengan simbol dari merek produsen. Skor terbesar yaitu 4,19 untuk promosi/diskon pada etalase toko menunjukkan bahwa untuk menarik perhatian konsumen perlunya penawaran/ diskon pada etalase secara apik dan menarik sehingga konsumen tertarik untuk mencari informasi atas produk tersebut dan masuk ke dalam toko. 


\section{Display toko Online}

Dari tabel 4.2 didapatkan skor terendah yaitu sebesar 3,69 pada pendeskripsian atas suatu produk karena konsumen masih merasa perlunya penambahan penjelasan mengenai produk dari pihak penjual barang. Skor terbesar yaitu 4,2 terdapat tulisan promosi/diskon dan penggunaan model foto yang menarik. Namun jika dilihat secara keseluruhan didapatkan hasil sebesar 3,945 dalam kategori "baik" dan lebih tinggi daripada yang diperoleh oleh toko offline sebesar 3,73. Hal ini disebabkan konsumen mendapatkan informasi mengenai: produk serta layanan dari toko online secara lebih mudah karena konsumen mendapatkan informasi tersebut secara dari gawai yang digunakannya untuk berbelanja. Selain itu tampilan homepage dari segi grafis menarik, terdapat tulisan penawaran spesial/diskon pada foto yang ditampilkan peletakan foto pakaian sesuai dengan kategorinya serta adanya deskripsi mengenai suatu produk.

Tabel 4.2

Rekapitulasi Variabel Display Toko Online

\begin{tabular}{|c|c|c|c|c|c|c|c|c|}
\hline \multirow{2}{*}{ No } & \multirow{2}{*}{ Pernyataan } & \multicolumn{5}{|c|}{ Jawaban } & \multirow{2}{*}{$\begin{array}{l}\text { Rata- } \\
\text { rata }\end{array}$} & \multirow{2}{*}{ Ket } \\
\hline & & STS & TS & KS & $\mathbf{S}$ & SS & & \\
\hline & $\begin{array}{c}\text { Display Pada Toko Online } \\
\text { (X2) }\end{array}$ & & & & & & & \\
\hline 1 & $\begin{array}{l}\text { Tampilan homepage dari segi } \\
\text { design grafis. }\end{array}$ & - & 4 & 154 & 122 & 120 & 3,89 & Baik \\
\hline 2 & $\begin{array}{l}\text { Terdapat tulisan penawaran } \\
\text { special/diskon pada foto yang } \\
\text { ditampilkan. }\end{array}$ & - & - & 42 & 238 & 120 & 4,2 & Sangat Baik \\
\hline 3 & $\begin{array}{l}\text { Menggunakan model foto } \\
\text { yang menarik. }\end{array}$ & - & - & 82 & 158 & 160 & 4,2 & Sangat Baik \\
\hline 4 & $\begin{array}{l}\text { Peletakan foto produk pakaian } \\
\text { sesuai kategorinya. }\end{array}$ & - & 1 & 120 & 158 & 121 & 3,99 & Baik \\
\hline 5 & $\begin{array}{l}\text { Terdapat deskripsi produk } \\
\text { pada setiap foto yang } \\
\text { ditampilkan. }\end{array}$ & - & 5 & 193 & 121 & 81 & 3,69 & Baik \\
\hline 6 & Adanya tambahan video. & - & 2 & 197 & 120 & 81 & 3,7 & Baik \\
\hline & Total & - & 12 & 788 & 917 & 683 & 3,945 & Baik \\
\hline
\end{tabular}

Sumber: Kuesioner diolah, 2019

\section{Pembahasan}

Produk yang dipajang pada etalase toko offline dapat menarik minat beli konsumen. Hal ini sesuai dengan pernyataan Widayanti (2013) yang menyatakan bahwa produk yang dipajang dapat memberikan pengaruh terhadap pembelian tidak terencana. Produk yang dipajang akan mampu memberikan nilai tambah bagi toko tersebut, bila ada tambahan penulisan promosi/diskon pada toko serta penulisan nama toko yang jelas dan besar dapat juga menarik perhatian konsumen. Penyusunan rak berdasarkan kategori jenis pakaian dan merek produsen serta penambahan poster dapat menjadi poin yang baik, sesuai dengan pernyataan Fitriana (2016) display interior berdasarkan pengelompokan barang dan penyusunan barang mempunyai pengaruh terhadap pembelian tidak terencana, hal ini membuat konsumen merasa mudah dan lebih tertarik untuk melihat kategori tiap jenis produk karena penyusunannya yang baik. Peletakkan produk baru di luar toko juga dapat menarik perhatian konsumen, Loya, et al(2015) menyatakan bahwa suatu produk yang telah di display, tingkat keberhasilannya menarik perhatian konsumen dipengaruhi juga dari kategori dan kepopuleran produk tersebut.

Produk yang dijual melalui tampilan homepage toko online lebih mengutamakan kemudahan dalam mengakses dan tampilan homepage tersebut. Hal ini sesuai dengan pendapat Shergill (2005) pembeli online memiliki evaluasi yang berbeda pada desain website yang diaksesnya. Selain itu penambahan tulisan penawaran spesial seperti promosi pada homepage dapat menjadi pembanding tersendiri bagi konsumen 
untuk mengakses lebih jauh. Penggunaan model yang menarik dan sesuai dengan pakaian yang ditampilkan serta penyusunan kategori produk pada website juga menarik perhatian konsumen. Ananda (2017) menyatakan bahwa fitur-fitur yang ditawarkan pada homepage memiliki daya tarik tersendiri melalui penyajian bentuk visual yang mampu menarik pelaku belanja online seperti: Terdapatnya deskripsi produk pada tiap foto yang ditampilkan (ukuran, bahan dan pilihan warna) sehingga calon pembeli mendapatkan gambaran yang jelas atas produk yang ditawarkan, serta adanya penambahan video dari produk yang ditawarkan dapat meningkatkan kepercayaan konsumen untuk melakukan pembelian. Perlunya memberikan kepercayaan pada konsumen untuk dapat menghasilkan keputusan pembelian sesuai dengan penelitian yang dilakukan oleh Suhari (2011) yang menyatakan bahwa kepercayaan pada internet dalam hal ini adalah berbelanja melalui toko online berpengaruh positif terhadap keinginan mencari informasi pada toko online tersebut dan menghasilkan niat beli.

\section{Uji Chi-Square/Kuadrat}

Uji ini adalah uji independensi, dimana suatu variabel tidak dipengaruhi atau tidak ada hubungan dengan variabel lain. $\chi 2$ bukan merupakan ukuran derajat hubungan. Didapatkan hasil sebagai berikut:

Tabel 4.3.

\section{Uji Chi-Square/Kuadrat}

\begin{tabular}{|c|c|c|c|}
\hline \multicolumn{4}{|c|}{ Chi-Square Tests } \\
\hline & Value & df & Asymptotic Significance (2-sided) \\
\hline Pearson Chi-Square & $851,705^{\mathrm{a}}$ & 104 & ,000 \\
\hline Likelihood Ratio & 592,680 & 104 &, 000 \\
\hline Linear-by-Linear Association & 33,593 & 1 &, 000 \\
\hline $\mathrm{N}$ of Valid Cases & 400 & & \\
\hline
\end{tabular}

Chi-square test digunakan untuk menguji apakah ada perbedaan antara Display pada toko offline dan Display pada toko online. Hasil chi-square menunjukkan nilai sebesar 851,705 dengan probabilitas signifikan 0,00. Oleh karena jika probabilitas $<0,05$ maka $\mathrm{H}_{0}$ ditolak, artinya terdapat perbedaan antara display toko offline dan toko online. Maka dapat disimpulkan bahwa terdapat perbedaan antara display toko offline dan toko online.

\section{Perbedaan Display toko offline dan Display toko online}

Penjualan secara offline dan online tentu saja berbeda dari segi menampilkan produk yang ditawarkan. Pada display toko offline, konsumen harus melihat secara langsung dan berinteraksi secara personal dengan tempat yang didatanginya. Berbeda dengan Display toko online, konsumen hanya mampu melihat produk yang ditawarkan melalui gadget atau HP saja. Sehingga penambahan informasi pada Display toko online harus lebih ditekankan lagi karena konsumen tidak dapat melihat secara langsung maupun menyentuh produk yang ditawarkan.

Kemudahan mengakses toko online yang dapat dilakukan dimana saja dan kapan saja telah menggeser keberadaan toko offline, hal ini dapat dilihat melalui hasil deskriptif yang menunjukkan perolehan rata-rata toko online lebih daripada rata-rata Display toko offline. Ini disebabkan beralihnya minat masyarakat ke internet karena daya tarik situs-situs belanja online lebih menarik, hal ini sesuai dengan penelitian yang dilakukan oleh Ananda (2017) dan Kumar (2014) 
Jurnal Manajemen dan Bisnis: Performa Vol.16, No. 2 September 2019

Tabel 4.4. Perbedaan karakteristik toko offline dan toko online

\begin{tabular}{|c|c|c|c|}
\hline No & Perbedaan & $\begin{array}{r}\text { Toko Offline } \\
\end{array}$ & Toko Online \\
\hline 1 & Tempat & Harus datang langsung ke toko & Toko dapat diakses di mana saja \\
\hline 2 & Waktu & $\begin{array}{l}\text { Lebih memakan waktu karena harus datang ke } \\
\text { toko }\end{array}$ & $\begin{array}{l}\text { Lebih efisien dalam waktu karena dapat } \\
\text { diakses kapan saja }\end{array}$ \\
\hline 3 & Informasi Produk & $\begin{array}{l}\text { Tergantung seberapa besar pengetahuan } \\
\text { pelayan toko }\end{array}$ & $\begin{array}{l}\text { Tergantung seberapa banyak informasi yang } \\
\text { dicantumkan }\end{array}$ \\
\hline 4 & Pilihan Produk & $\begin{array}{l}\text { Kurang bervariasi karena satu toko belum tentu } \\
\text { lengkap dan akan menghabiskan banyak waktu } \\
\text { bila ke toko lainnya }\end{array}$ & $\begin{array}{l}\text { Lebih bervariasi karena dapat mengakses } \\
\text { banyak toko online dalam waktu singkat }\end{array}$ \\
\hline 5 & Kualitas & $\begin{array}{l}\text { Dapat langsung dipastikan karena bisa disentuh } \\
\text { dan dicoba }\end{array}$ & $\begin{array}{l}\text { Tidak dapat dilihat secara langsung sehingga } \\
\text { kurang meyakinkan }\end{array}$ \\
\hline 6 & Harga & Dapat menawar barang yang dijual & Tidak dapat menawar, harga sudah fix \\
\hline
\end{tabular}

Sumber: Data diolah, 2019

Hal ini sesuai dengan penelitian yang dilakukan oleh Mahajan dan Saini (2018) yang menyatakan bahwa terdapat beberapa perbedaan diantara toko offline dan online, namun perbedaan tersebut tidak mematikan pasaran dan sistem penjualan yang dilakukan diantara keduanya. Karena perbedaan tersebut menjadikan kedua toko menjadi unik. Berdasarkan kemudahan mengakses toko online, menjadikannya lebih mudah untuk diakses oleh konsumen. Sedangkan faktor-faktor lainnya adalah berdasarkan atas pengalaman belanja yang pernah dilakukan oleh seorang konsumen sebelumnya.

\section{KESIMPULAN DAN SARAN}

\section{Kesimpulan}

Berdasarkan pengolahan data hasil penelitian, maka dapat disimpulkan bahwa Hasil deskriptif pada Display toko offline dan Display toko online menunjukkan hasil baik dikarenakan konsumen merasa bahwa display yang ditampilkan pada kedua jenis toko dapat dipahami dan sesuai dengan harapan konsumen. Namun hasil pada Display toko online lebih tinggi sedikit daripada Display toko offline. Hal ini disebabkan kemudahan yang ditawarkan di Toko Online. Sedangkan Berdasarkan hasil perhitungan chi-square didapatkan bahwa terdapat perbedaan antara Display toko offline dan Display toko online. Perbedaan dari segi menampilkan produk yaitu secara langsung atau offline dan online di mana pada Display toko offline konsumen dapat melihat secara langsung melihat dan mencoba produk yang dipajang. Sedangkan pada Display toko online konsumen hanya mampu melihat melalui tampilan homepage pada HP tanpa dapat melihat dan mencoba secara langsung.

\section{Saran}

Produsen Display toko offline dapat meningkatkan tampilan tokonya dengan lebih sering memajang produk terbarunya di etalase serta harus terus memperbaharui produknya sesuai dengan tren fashion saat itu. Penyusunan produk lebih disesuaikan dengan kategori jenis dan merek produk, meningkatkan keragaman produk, serta lebih sering mengadakan promosi untuk meningkatkan pembelian. Pada Display toko online, perhatian utama pada kemudahan mengakses toko, secara berkala memperbaharui laman tampilan websitenya. Sehingga produk yang ditawarkan lebih up to date dan konsumen tertarik untuk melihat secara teratur. Namun untuk orang-orang tua yang tidak familiar dengan belanja online akan menjadi kelemahan 
bagi toko online untuk menyasar mereka. Sehingga untuk menarik minat orang-orang tua tersebut adalah dengan meningkatkan iklan pada media TV, sehingga dapat meningkatkan keinginan orang-orang tua untuk beralih belanja online.

Saran untuk peneliti selanjutnya adalah agar sumber data real yang terkait dengan penduduk dapat diperoleh melalui website resmi pemerintah. Jika memang terdapat perbedaan, apa pentingnya menunjukkan perbedaan tersebut. Sertai dasar pemikiran dari penelitian terbaru dengan jumlah yang lebih banyak. Penggunaan metode untuk melihat perbedaan dari dua jenis toko dapat lebih dieksplor dengan tidak hanya menggunakan chi-square test.

\section{DAFTAR PUSTAKA}

Alfiyah, S. (2017). Pengaruh atmosfer toko, display toko, dan kelengkapan produk terhadap keputusan pembelian pada toko Samu Pace. Universitas Nusantara PGRI Kediri.

Agustin, J., dan D. Koeshartono. (2014). Pengaruh Karateristik Website Terhadap Kepuasan Konsumen dan Dampaknya Pada Kepercayaan Konsumen. Studi Kasus Di Yogyakarta. Fakultas Ekonomi Universitas Atmajaya Yogyakarta, hal 1-14.

Ambarwati, D. A. S. (2015). Analisis perbandingan Loyalitas Konsumen Pada Online Shop dan Toko Konvensional (Brick and Mortal Store). Universitas Lampung.

Ananda, L. D. (2017). Dinamika Trust Pada pemasaran Online di Media Sosial. Jurnal Komunikasi Indonesia. Vol. V No. 1. April 2017. ISSN 2301-9816, hal. 14-25.

Artikel Tentang Ilmu Pengetahuan Umum. (2019). Jumlah Penduduk Indonesia (diurutkaan berdasarkan Provinsi). Diakses Pada Tanggal 15 Maret 2019. https://ilmupengetahuanumum.com/10-kotaterbesar-di-indonesia-menurut-jumlah-penduduknya

Bilgihan, Anil, Tingting Zhang, Jay Kandampully. 2016. Towards a unified customer experience in online shopping environments. International Journal of Quality and Service Sciences. Vol. 8 No. 1, 2016 pp. 102-119

Buchari Alma. 2009. Manajemen Pemasaran dan Pemasaran Jasa. Bandung:Alfabeta.

Clement, J. (2007). Visual influence on in-store buying decisions: an eye-track experiment on the visual influence of packaging design. Journal of Marketing Management, 23(9-10), 917-928.

Fatimah Kartini Bohang. (2018). Artikel ini telah tayang di Kompas.com dengan judul "Berapa Jumlah Pengguna Internet Indonesia?". Diakses Pada Tanggal 15 Maret 2019, https://tekno.kompas.com/read/2018/02 /22/16453177/berapa-jumlah-pengguna-internet-indonesia.

ISSN: 1829-8680 E-ISSN: 2599-0039 
Fritiana, A. (2016). Analisis Pengaruh Display Interior Terhadap Perilaku Pembelian Impulsif Konsumen Indomaret Pontianak. Jurusan Sistem Infomasi, STMIK Pontianak. Journal of Applied Intelligent System, Vol. 1, No.2, Juni 2016, hal. 90 -102.

Gajanayake. Ridmi, Sashini Gajanayake.2011. The Impact of Selected Visual merchandising Techniques On Patronage intentions In Supermarket ( Study Based On Colombo District). Proceeding 2nd international Conference on Business And Economic research (ICBER)

Gudonavičienè, R., \& Alijošienė, S. (2015). Visual Merchandising Impact on Impulse Buying Behaviour. Procedia - Social and Behavioral Sciences, 213, 635-640.

Gupta, P. (2015). Comparative Study Of Online and Offline Shopping A Case Study of Rourkela in Odisha. Rol ND-413HS1007.

Grewal Dhruv, Anne L. Roggeveen, Jens Nordfält.2017. The Future of Retailing. Journal of Retailing 93 (1, 2017) 1-6.

Jusoh, Z. M dan Ling, G. H. (2012). Factors Influencing Consumers' Attitude Towards E-Commerce Purchases Through Online Shopping. International Journal of Humanities And Social Science. Vol. 2 No. 4 [Special Issue - February 2012] hal. 223-230.

Katawetawaraks, C \& Cheng, L.W. (2011). Online Shopper behavior: Influencing of Online Shopping Decision. Asian Journal of Business Research, 1(2), hal 66-74.

Katrandjiev, Hristo, Ivo Velinov. 2014. Investigation of Online Visual Merchandising (OVM) Elements of Apparel Web Stores. Economic Alternatives, Issue 1,

Kumar, V. (2014). “A study on Needs of Visual Merchandising for Online \& Physical Stores”. 2014. IOSR Journal of Business and Management) e-ISSN: 2278-487X, p-ISSN: 2319-7668. Volume 16, Issue 9.Ver. VI (Sep. 2014), PP 98-101.

Levy, M., Weitz, B. A., \& Grewal, D. (2014). Retailing Management (nineth). NewYork: Mc Graw Hill.

Loya, S., Ismail, S., dan Khan, M. Z. (2015). Impact Of In-Store display on Sales A Comparative Study Among New And Mature Product. International Journal of Humanities and Social Science. Vol. 5, No. 11; November 2015, hal. 188-196.

Mahajan, S. dan Saini, N. (2018). A Comparative Study on Online and Offline Shop. International Research Journal of Management and Commerce. Vol.5, Issue.4, ISSN 2348-9766, hal.151-169.

Medcom. (2019). 50Juta Penduduk Indonesia Terkena Wabah Belanja Online. Diakses Pada Tanggal 16 Maret 2019. https://www.medcom.id/ekonomi/mikro/4bazvrZk-50-juta-penduduk-indonesiaterkena-wabah-belanja-online

Merugu, P., \& Vaddadi, K. M. (2017). Visual Merchandising: ( A Study on Consumer Impulsive Buying Behaviour in Greater Visakhapatnam City ). International Journal of Engineering Technology Science and Research, 4(7), 915-927. 
Mulyadi, Ivan (2015), Virtual Store Belum Gantikan Brick and Mortar, Majalah Marketing Edisi 01/XV/Januari/2015. Pp 66-67.

Novianti, R. (2014). Pengaruh Display Toko Dan Kelas Sosial Terhadap Keputusan Pembelian Pada Galery M\&N Design Bandung. Universitas Komputer Indonesia. repository.unikom.ac.id/27046/

Rahadi, D. R. (2013). Pengaruh Karateristik Website Terhadap Kepuasan Pelanggan Masyarakat Kota Palembang. Jurnal Manajemen dan Bisnis vol.5 No.7

Santy, D. R. (2016). Display toko, Gaya Hidup Dan Pembelian Impulsif (Penelitian Pada Konsumen Surf Inc Bandung). Program Studi Manajemen - Fakultas Ekonomi Universitas Komputer Indonesia. Majalah Ilmiah UNIKOM Vol.11 No. 1, hal.87-102.

Shergill, G. S. dan Chen, Z. (2005). Web-based Shopping. Consumers' Attitudes Toward Online Shopping in New Zealand. Journal of Electronic Commerce Research, VOL. 6, NO.2, 2005, page. 79-94.

Siagian, H., dan Cahyono, E. (2014). Analisis Website Quality, Trust dan Loyaliti Pelanggan Online Shop. Jurnal Manajemen Pemasaran Universitas Kristen Petra. Vol.8, No.2, ISSN 1907-235X. doi: 10.9744/pemaasaran.8.2.55-61.

Startup Bisnis. (2018). Pertumbuhan Bisnis E-Commerce di Indonesia. Diakses Pada Tanggal 17 Maret 2019. https://startupbisnis.com/Bisnis-Ecommerce-di-Indonesia.

Sugiyono. (2014). Metode Penelitian Kuantitatif, Kualitatif, dan R\&D. Bandung: Penerbit Alfabeta.

Suhari. (2011). Kepercayaan Terhadap Internet Serta Pengaruhnya Pada Pencarian Informasi dan Keinginan Membeli Secara Online. Jurnal Dinamika Informatika.

Widayanti, D. A. (2013). Pengaruh Penataan Produk Terhadap Pembelian Tidak Terencana Pada Indomaret. Universitas Muhammadyah Malang. http://eprints.umm.ac.id/20204/1 